\title{
Association of Islet Cell Antibody and Human Leucocyte Antigen DQB1 Alleles (0201/0302) in siblings of type 1 diabetes mellitus
}

\author{
*Hassan Z.A., *Kandeel H.T., *Abaza D.M. ***Bostamy H.F. **Hssan H.A. \\ *Endocrinology and **General Medicine Departments - Al Azhar University (girls) \\ ***Biochemistry Department - Cairo University
}

\begin{abstract}
Type 1 diabetes is most often associated with auto antibodies (AAbs) against beta cell antigens and high levels of HLA mediated genetic susceptibility. The purpose of this study was to identify at risk siblings of type1 diabetic patients at an early stage by screening for HLADQB1 alleles, which carry the high-risk genotype (DQB1*0201 / 0302) and its associations with measured islet cell antibody (ICA). Twenty-five siblings of subjects with type 1 diabetes aged $4-13 \mathrm{yr}$, median age $(8.4 \pm 1.02)$ were studied. They were screened for ICA as well as HLA-DQB1 (0201 and 0302) alleles.

Results of the study showed that among the 25 siblings, $20 \%$ tested positive for ICA. HLA-DQB1 was detected in $16 \%$ of siblings. Allele DQB1 0201 presented higher frequency (48\%) than DQB1 $0302(36 \%)$. Association of DQB1 0201 and / or 0302 with ICA positive cases was detected in $20 \%$ of cases, while frequency of DQB1 0201 and / or 0302 in ICA negative cases was detected in $48 \%$ of them.
\end{abstract}

In conclusion: - Our results showed that among siblings of type 1 diabetes HLA-DQB1 alleles associated with highest genetic susceptibility i.e. DQB1 0201 and / or 0302 were detected with high significance. Also HLA-DQB1 0201 is more frequently associated with ICA.

Initial screening by high risk DQB1 $* 0201 / 0302$ with subsequent autoantibody testing is shown to be useful in the assessment of diabetes risk among siblings of subjects with type 1 diabetes.

\section{Introduction}

Type 1 diabetes is most often associated with auto antibodies ( AAbs ) against "beta" cell antigens as AAbs to glutamic acid decarboxylase (GADA), insulin (IAA) as well as the heterogeneous islet cell cytoplasmic antibodies (ICA).

Although the complex associations and linkage of HLA antigens with type 1 diabetes are not yet fully understood, HLADQB1 and DQA1-DQB alleles provide the strongest genetic contribution to the disease (Robinson etal, 1989) accounting for approximately $50 \%$ of the genetic risk in type 1 diabetes ( Todd and Farral 1996).

In Caucasian, DQB1 0302 and DQB10201 and their linked DR specificities DR4 and DR3 provide disease susceptibility (Michelson et al,1990), where's dominant protection is conveyed by DQB1 0602 linked to DR2 (Reijonen et al, 1991). The relationship between HLA markers and the occurrence of AAbs has been previously examined in recent onset patients of type 1 diabetes indicating positive correlation (Vande walle et $a l, 1997)$ in recent years, several studies have been conducted to identify subjects at risk of developing type 1 diabetes by screening for ICA as well as by human leukocyte antigen (HLA) typing.

\section{Aim of the work}

To identify at risk siblings of type 1 diabetic patients at an early stage, by screening for HLA-DQB1 alleles which carry the high-risk genotype (DQB1 0201 and 0302) and its associations with measured islet cell antibody (ICA). 


\section{Subjects and methods}

This study was carried out on twentyfive healthy siblings of type 1-diabetes. Fourteen females and 11 males. They aged 4-13 years, mean age was $(8.4 \pm 1.02)$.

Samples of serum and blood were collected for immunological and HLA allele typing test, respectively. $\mathrm{HbA1c}$ was also measured.

Each family provided informed consent before samples were collected.

\section{Methodology of HLA typing}

Whole blood on EDTA was obtained from each subject. DNA was extracted from whole blood using DNA extraction kit (Manufactured by QIAGEN, USA) according to recommendation.

HLA DQB1 typing for both of the studied alleles was carried on using polymerase chain reaction (PCR) kit using sequence specific primaries multiplex PCR (all set SSP) manufactured by (DYNL BIOTECH Ltd. UK.). PCR cycling parameters were as followed: A denaturation step at 96 degrees centigrade $\left(c^{\circ}\right)$ for two min., 10 cycles of denaturation at $96 \mathrm{c}^{\circ}$ for $15 \mathrm{sec}$., annealing and extension at $96 \mathrm{c}^{\circ}$ for $60 \mathrm{sec}$. Twenty cycles of denaturation at $96 \mathrm{c}^{\circ}$, for $10 \mathrm{sec}$. annealing at $61 \mathrm{c}^{\circ}$. for $50 \mathrm{sec}$., and finally extension at $72 \mathrm{c}^{\circ}$. for $30 \mathrm{sec}$. (Ilonen et al, 2000).

\section{Immunological studies}

ICA was determined by indirect immunofluorescence (IIF), (Reijonent et al 1994).

The ICA assay was controlled externally by an international proficiency test, (Immunology Diabetes Workshop, University of Florida USA, 1993).

The DNA locus of HLADQB1 genotype was typed using the amino acid sequencer of DNA (Sequence Specific Oligonucleotide) (SSO) probes 6.(Adojaan, et al 1996)

\section{Statistical methods}

Mean values, ranges and standard deviations were obtained for normally distributed values. Percentage of results were also calculated

\section{Results: -}

The results are shown in tables 1,2 , and 3

Table (1) mean value \pm SD of age / year $-\mathrm{FBS} / \mathrm{mg} / \mathrm{dl}$ and HbA1c for all studied cases(25).

\begin{tabular}{|l|l|l|l|}
\hline & Age / year & FBs $/ \mathrm{mg} / \mathrm{dl}$ & $\mathrm{Hb}$ A1c \\
\hline Range & $4-13$ years & $65-101 \mathrm{mg} / \mathrm{dl}$ & $4.2-6.3$ \\
& & & \\
mean & $(8.4 \pm 1.02)$ & $(84.8 \pm 5.07)$ & $(6.26 \pm 1.58)$ \\
\hline
\end{tabular}

Table (2) percentage of -ve and +ve HLADQB1 0201,0302 and ICA in all studied cases.

\begin{tabular}{|l|l|l|}
\hline Parameters & $-\mathrm{ve}$ & $+\mathrm{ve}$ \\
\hline HLADQB1 0201 & $52 \%$ & $48 \%$ \\
\hline HLA-DQB1 0302 & $64 \%$ & $36 \%$ \\
\hline $\begin{array}{l}\text { HLADQB1 0201 and } \\
0302\end{array}$ & $84 \%$ & $16 \%$ \\
\hline ICA & $80 \%$ & $20 \%$ \\
\hline
\end{tabular}


Table (3) Frequency of Association of HLADQB1 0201 and 0302 with positive and negative ICA.

\begin{tabular}{|l|l|l|l|l|}
\hline & $\begin{array}{l}\text { HLADQB1 } \\
0201\end{array}$ & $\begin{array}{l}\text { HLADQB1 } \\
0302\end{array}$ & Total & Percentage \\
\hline ICA (-ve) & $7(28 \%)$ & $5(20 \%)$ & 12 & $48 \%$ \\
\hline ICA (+ve) & $3(12 \%)$ & $2(8 \%)$ & 5 & $20 \%$ \\
\hline
\end{tabular}

\section{Discussion:}

Type 1 diabetes is an autoimmune disease caused by destruction of pancreatic insulin secreting B-Cells, a process that may occur sub clinically years before the onset of clinical symptoms. The risk of sibling is 15 fold higher than is the population prevalence, but the etiology of the disorder is complex and probably involves multiple genetic and environmental factors (Charles et al, 1998).

Among the general population, the presence of islet autoantibodies carries increased risk (Schatz et al, 1993). Thus it would appear that islet autoantibodies are universal markers of the destruction of insulin producing islet cells that ultimately results in type 1 diabetes.

In the present study, ICA were used as primary screening tool for beta - cell autoimmunity in siblings with increased genetic risk of type 1 diabetes. This decision was based on the observation that ICA were more sensitive and specific than GADA or IAA, with more than $84 \%$ of children with newly diagnosed type 1 diabetes testing positive (Savila et al,1998 and Kimpim etal, 2002).

In the current study, ICA were detected in $20 \%$ of studied cases. Kulmala et al,(2001) reported that the prevalence of ICA had been observed to be $3-4 \%$ among Finnish school children, while Krischer et al (2003) found $82 \%$ positive cases of ICA. Further follow up and analysis of actual progression to diabetes may revert some of our negative ICA cases to positive one. Bonifacio et al, (1999) had shown that ICA titer was directly related to risk of type 1 diabetes. Also for trails in which screening is necessary to identify a population with sufficient diabetes risk, ICA would augment the population identified by GADA and ICA 512 AA (or vise versa).

Type 1 diabetes has strong class II HLA association, with linkage to the DQA and $\mathrm{B}$ genes and is influenced by the DRB genes. The risk presented by the DR4 allele is primarily attributable to an association in a haplotype with HLA-DQB1 *0302. Susceptibility associated with HLA-DR 3 may be determined directly by HLA-DQB1 *0201 (Cavan etal, 1992).

In the current study, high risk HLADQB1 0201 allele represented higher frequency in siblings of type 1 diabetes (48\%) than HLA-DQB1. 0302 allele (36\%). Analysis for both HLA-DQB1allele was found in $16 \%$ of cases. These results are in agreement with Hagopain (1995) and Bonifacio et al (1995).

High proportion of this genetic marker indicate that those siblings carry the susceptibility for developing type 1 and that their predicted risk of diabetes is greater with more than one high risk allele.

In a study, investigating genetic and hum-oral markers for prediction type 1 diabetes in siblings has reported that among the genetic markers DQB1 *0201/0302 was associated with the highest positive predictive value of $22 \%$ (Schlosser et al, 2002).

In our study, the frequency of HLADQB1 *0201 and / or 0302 in ICA negative cases was detected in $48 \%$ of cases. This is in accordance with results of Schlosser et al (2002), who found $46 \%$ association.

On the other hand HLA-DQB1 *0201 and / or 0302 was detected in $20 \%$ of our ICA positive cases. Kimpini et al, (2002) 
found the proportion of children who tested positive for ICA was significantly higher among those with the high risk genotype $(5.1 \%)$.

Schlosser et al (2002) found HLA heterozygostiy to occur in $4.5 \%$ with single $\mathrm{AAb}$.

ICA was associated with 0201 in $8 \%$ of cases and was associated with both alleles in $12 \%$ of cases. Subjects with positive AAbs revealed an increased frequency of diabetes when associated with HLA-DQB1 alleles 0201 or $0302(\mathrm{P}=0.001$ and 0.006) respectively (Kimpim etal, 2002).

Vandewalle et al, (1997) in their study on recent onset diabetic patients as well as their siblings found positive correlation between the occurrence of diabetes associated AAbs and high risk HLA markers. These results might be of importance for population screening strategies based on detection of islet autoantibodies in associations with high risk HLA genotypes. Furthermore they indicate significant increased risk for subsequent development of type 1 diabetes.

In conclusion: - our results showed that among siblings of type 1 diabetes HLADQB1 alleles associated with highest genetic susceptibility i.e. DQB1 0201 and / or 0302 were seen with high significance. Also HLA-DQB1 0201 is more frequently associated with ICA. Initial screening by high risk DQB1 *0201/0302 with subsequent autoantibody testing is shown to be useful in the assessment of diabetic risk among siblings of subjects with type 1 diabetes.

\section{References}

1. Adojaan B, Knip M, Vahasalo P, et al (1996). Relation between incidence of childhood IDDM and frequency of ICA positivity in un affected children in the general population. Diabetes Care; 19:1451-1452.

2. Bonitacio E, Bmgly PJ, Shallock M, Dean BM, et al (1990) Quantity of islet cell antibodies and prediction of insulin dependent diabetes .Lancet 335; 147-149
3. Cavan DA, Bain SC, Barnett AH: Genetics of type 1 (Insulin-Dependent) diabetes mellitus med. Genet. 29:441446.

4. Charles FV, Pnina V,Sunanda B, Fei Bao., et al (1998) Evidence For Oligogenic Inheritance of type 1 diabetes in a large Bedouin Arab Family. J. Clin. Investigation 102 (8) 1569-1575

5. Culmala P, Rahko J ,Savola K, Salo P, et al. .(2001) (Beta) cell autoimmunity, genetic susceptibility and progretion to type1diabetes in unaf-fected school children. Diabetes Care24: 171173

6. Green baum C J, Sears KL, Kahn SE,Palmer JP. .(1999) Relationship of B-cell Function and autoantiboies to progression and non progression of subclinical type 1 diabetes Diabetes 48:170-175

7. Hagopain W,Sanjeevi C,Kockum I et al (1995) Glutamate decarboxylase, insulin and islet cell antibodies and HLA typing to detect diabetes in a general population based study of Swedish children. J Clin Inv; 95;001-7

8. Ilonen $\mathbf{J}$, Reijonen $\mathbf{H}$, Green $\mathbf{A}$, Reunanen A ,et al (2000) Childhood diabetes in Finland study group. Geographical differences with Finland in the frequency of HLA- DQ genotypes associated with type 1 diabetes susceptibly. Eur. J. Immunogenet; 27: 225-230.

9. Kimpim KI, Kulmala P, Savoca K, Kupila A, et al. .(2002) Natural history of beta cell autoimmunity in young children with increased genetic susceptibility to type1 diabetes recruited from the general population.J. Clin.Endo.Metab. 87(10) 4572-79

10. Krischer JP, Cuthbertson DD, YU, liping I, et al. (2003). The diabetes prevention trial type1 study group. Screening Strategeis for the. Identification of Multiple Antibody-Positive Relation of individuals with Type1 Diabetes. J. clin. Endo. Metab. 88(1): 103-108

11. Michelson B ,Wassmuth R, Ludvlgsson J, Lrnmark A, et al.(1990). HLA hterozygosity in insulin dependent diabetes is most frequent at DQ locus. Scan. J. Immunology 31:405-413

12. Pugliese A, Eisenbarth GS. (1996). Human type1 diabetes mellitus: genetic susceptibility and Resistance inisenbarth 


\section{Association of Islet Cell Antibody.......}

GS, Lafercy KJ eds. Type1diabetes: molecular, cellular and clinical immunology. Oxford University Press; 134-152.

13. Reijonen $\mathbf{H}$, Ilonen J, Knip $\mathbf{M}$, Kerblom HK, .(1991) HLADQB1 Alleles and agsence of Asp-57 suscept factors of IDDM in finland. Diabetes. 40:1640-44

14. Robinson, DM, Holbeck S, Plammei J, Nepom GT. (1989). HLADQ3.2 identifies subtypes of Dr4 Haplotype permissive for IDDM. Genet. Epidemiolology 6:149-154

15. Savola K, Bonifacio E, Sabbah E, Kuolmala P, Salo P et al. .(1998). The childhood diabetes in Finland study group .IA-2 antibodies -a sensitive marker of IDDM with clinical conception childhood adolecance. Diabetologia 41:424-79

16. Schatz D, Krischer J Horne G, Riley W,Spillar R, et al. .(1994). Islet cell antibodies predict insulin-dependent diabetes in United state school age children as powerfullyas in unaffected relatives.J.Clin. Invest.;93:2403-2407

17. Schlosser, Michael, trebelow, Martina, Wassmuth. et al (2002). The Karlsburg Type 1 diabetes Risk Study of a Normal School Children Population: Association of (beta) -cell auto antibodies and Human Leucocytic antigen-DQB1 alleles in Antibody-Positive Individuals . J. Clin.End. Metab . 87(5) 2254 - 61,

18. Todd JA, and Farralm: (1996). Panning for gold: genome wide scanning for link age in type1 diabetes. Hum. Mol.Genet. 5:1443-1448

19. Vandewalle CL, Farlorni A, Lernmark, Goubert $P$,et al. .(1997). Association of GAD65-and LA-2 autoantibodies with genetic risk markers in new-onset IDDM patientsand their siblings. The Belgiam Diabetes Registng. Diabetes care 20:1547-1552 
مصاحبة الاجسام المضادة لخلايا جزر لانجرهاتز مع الجزيء الجينى DQB1 0302

\section{1 في اشقاء مرضى السكر من النوع الاول}

*د. زينب عبد الباسط ـ *د. هناء طه قنديل ـ *د. دينا اباظة ـ ** د. د. حنان

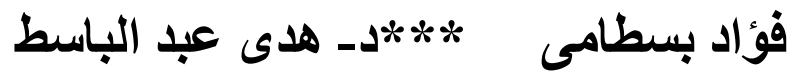

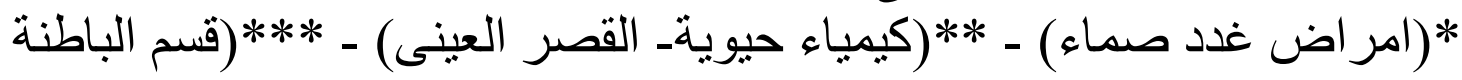
العامة)

السكر من النوع الأول هو اكثر الانواع مصحوبة بظهور الاجسام المضادة ضد خلايا البيتا

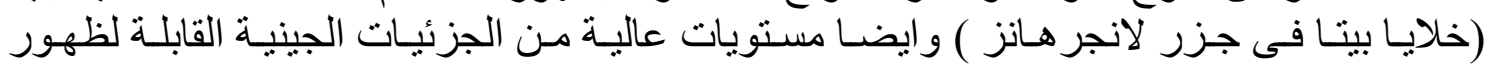
المرض (خدف الهذف من هذا البحث هو تحديد مدى قابليـة تعرض اثتقاء مرضى السكر من النوع الاول لهذا

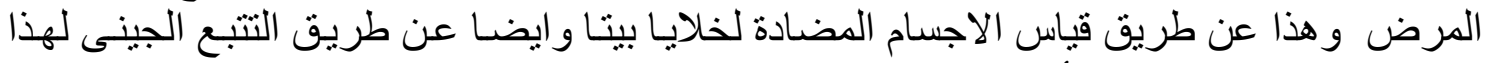

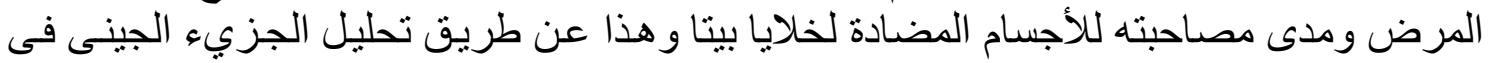

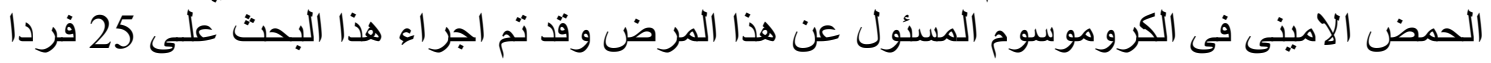

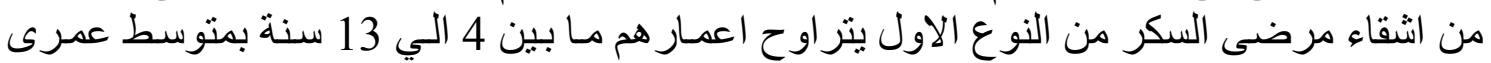

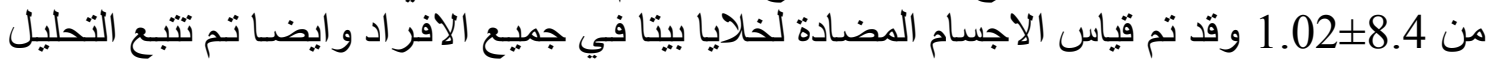

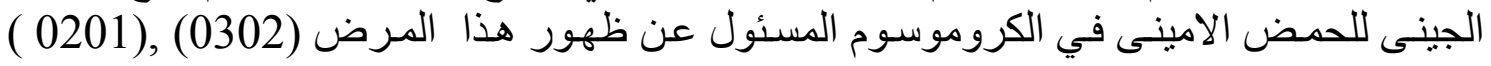

HLA-DQB

وكانت النتائج الاتى

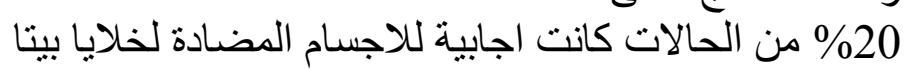

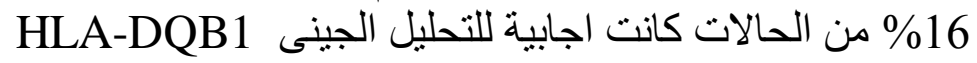

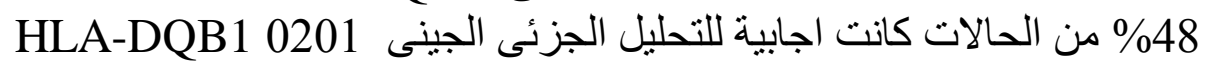

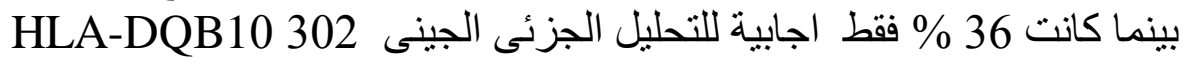

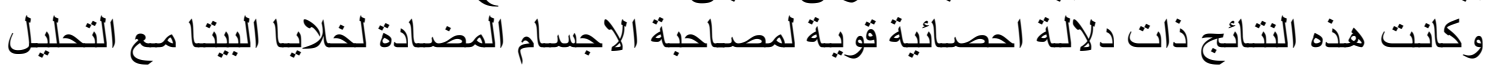

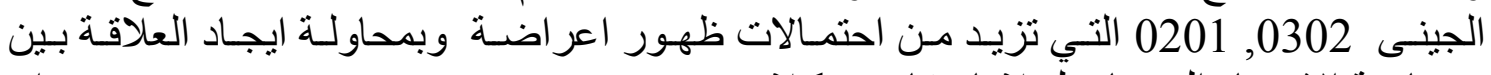

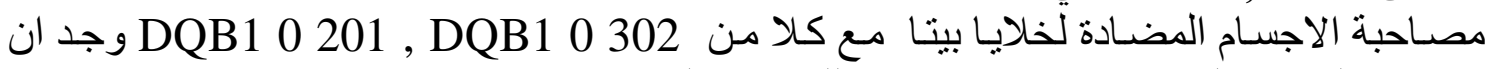

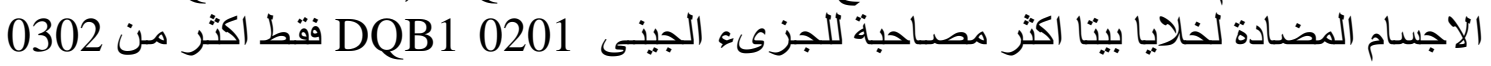

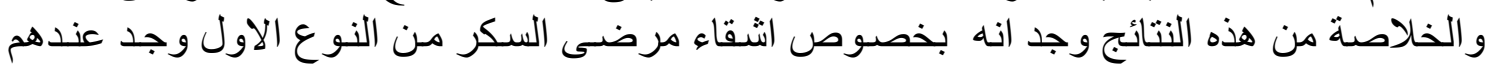

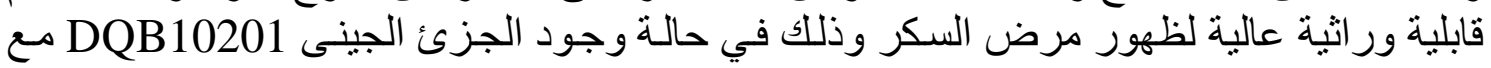

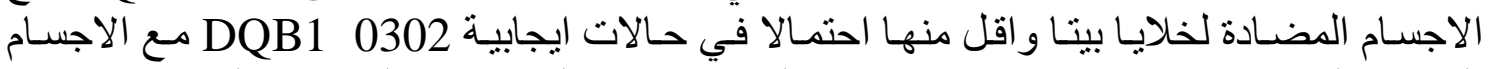

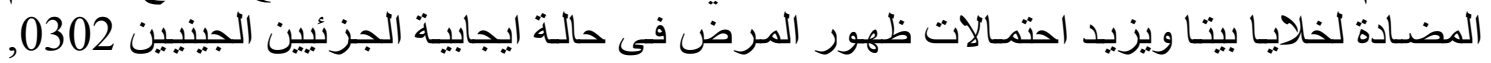

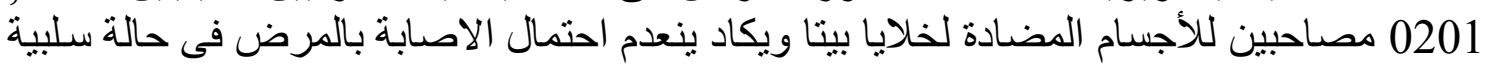

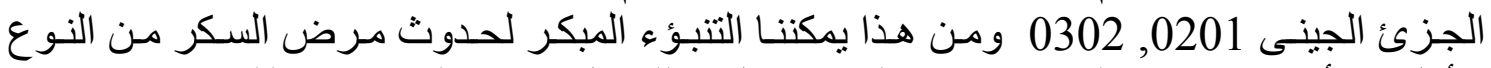

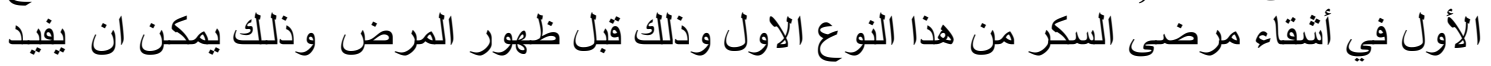

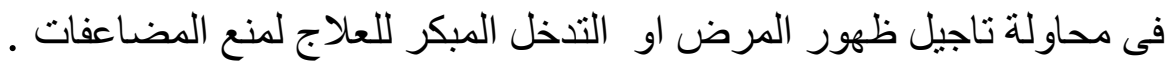

